\title{
Evaluation of the Influence of Various Biodegradable Packaging Materials on the Quality and Shelf Life of Different Food Products
}

\author{
Lija Dukalska*, Eva Ungure, Ingrida Augspole, \\ Sandra Muizniece-Brasava, Vita Levkane, Rakcejeva Tatjana \\ Department of Food Technology, LLU \\ Inta Krasnova \\ Latvia State Institute of Fruit Growing
}

\begin{abstract}
The aim of the present research was to summarize the results of investigations carried out on the influence of different biodegradable polymer packaging materials on the shelf life and quality of several food products during storage. In Latvia, most of consumers consider that polymers as a material for food packaging are overly used, and they support the idea of introducing new eco-friendly food packaging. Biodegradable films were investigated for their ability to extend the shelf life of apple salad and minimally processed shredded carrots stored at $4{ }^{\circ} \mathrm{C}$. It was found that they can guaranty the same as or even a longer shelf life than that provided by conventional polymer films. Bio PLA transparent films, thermoformed PLA containers, and cellulose-based films were tested for fresh produce packaging. Ceramis ${ }^{\circledR}-\mathrm{PLA}-\mathrm{SiOx}$ barrier coated films were tested for their influence on the quality of food products - rye bread, apple-black currant marmalade candies, and soft cheese Kleo - during storage. PLA and PHB films showed satisfactory results for packaging of perishable foods salad with meat in mayonnaise. Ceramis ${ }^{\circledR}-\mathrm{PLA}-\mathrm{SiOx}$ films were used for vacuum packaging and also for mild thermal treatment (Sous vide) of soft cheese, providing its prolonged shelf life. Some BoPLA films specially envisaged for packaging of confectionery were tested for milk pomade sweet - sherbet - packaging. Its quality was evaluated mainly by moisture content and by changes in hardness during storage. The results suggest that biodegradable packaging materials can be a successful alternative to the conventional polymers for packaging of several food products, which could provide an essential contribution in reducing the environmental pollution. Key words: Biodegradable polymers, foods, food quality, packaging, shelf life.
\end{abstract}

\section{Introduction}

Food packaging performs an essential function to extend the shelf life, maintain the quality and safety of the packed goods, but packaging materials can have a negative impact on the environment (Lopez-Rubio et al., 2004). Conventional polymers made of petroleum-based raw materials are a widely used packaging for foods (Baner \& Piringer, 1999). Nowadays, bio-based packaging for foodstuffs becomes increasingly popular, and it is being used as a replacement for conventional polymers (Avella et al., 2008; Farris, Schaich, Liu, Piergiovanni, \& Yam, 2009).

Bio-based food packaging materials are a new direction in food industry (Robertson, 2008). Those materials have been defined as 'materials derived from renewable sources' (Van Tuil, Fowler, Lawther, \& Weber, 2000). The influence of biodegradable materials on food product quality at the storage time has not been sufficiently investigated for different kinds of foods. By replacing at least some part of conventional polymer materials, decomposition time of which exceeds 100 years, with compostable biomaterials, which decompose in soil within few months due to the influence of microorganisms and humidity, the society could reduce the expenses for collection and sorting of the used packaging, its recycling, and landfill management (Grengross \& Slater, 2000).

Ecolean, developed as one of the first environmentally friendly materials, consists partly of conventional plastic polyethylene (PE) or polypropylene (PP) and partly of the nature's own material - chalk ( $40 \%$ by weight) (Ecolean $\mathrm{AB}$, 2012).

PLA (polylactic acid) films, produced from lactic acid, have shown the highest commercial potential and are now produced on a comparatively large scale.

\footnotetext{
* Corresponding author's email:

Lija.Dukalska@1lu.lv
} 
Biodegradable PLA, made from annually renewable resources and marketed under the trade name "Nature Works PLA", complies with the appropriate food contact regulations not only of the EU member states and the USA but also of the majority of other countries of the world. It may be used in direct contact with all types of food and, according to EN 13432, is certified as compostable in commercial composting facilities (Eilert, 2005). In the last few years, the use of PLA as a packaging material has increased in Europe, Japan, and the United States - mainly in the area of fresh produce (Arvanitoyannis \& Kasaveti, 2008). Biopolymers show some limitations in terms of performance like thermal resistance, barrier and mechanical properties, associated with the cost (Siracusa, Rocculi, Romani, \& Rosa, 2008).

Most bioplastics of the past have had the major drawback that they could not withstand high temperatures. Natural PLA products have a temperature resistance between $-20{ }^{\circ} \mathrm{C}$ and $+50{ }^{\circ} \mathrm{C}$. The company "Purac" has developed a solution with a high heat PLA variety that can withstand temperatures up to $95-120{ }^{\circ} \mathrm{C}$, e.g. application in drinking cups for hot drinks (Purac, 2012). This improved heat performance is now commercially available.

PLA can be made into films, co-extruded into laminates, thermoformed and injection stretch blow moulded into bottles (Auras, Harte, \& Selke, 2004). Its major application to date has been as food service containers, and PLA trays and films. Auras, Singh \& Singh (2005) evaluated oriented polylactide (OPLA) for fresh food service containers and compared it with polyethylentereftalate (PET) and oriented polystyrene (OPS).

The possibility for the use of biopolymers, such as poly-3-hydroxybutyrate (PHB) and PLA, in paper coating for food packaging has been investigated. PHB coated paper showed higher water resistance but lower oil resistance than PLA coated paper (Shawaphun \& Manangan, 2010).

Nowadays, new biodegradable materials are produced with improved barrier properties, for instance, Ceramis ${ }^{\circledR}-\mathrm{PLA}-\mathrm{SiOx}$ coated film (Packagingeurope, 2009) - the world's first biodegradable flexible barrier film derived from renewable natural resources - is certified by DIN CERTCO and entitled to bear the compostability logo. Using Ceramis ${ }$-PLA-SiOx, Alcan has devised the Bio-Pack for snack foods, pet food, fresh food, and dairy products (Europe's Packaging ..., 2007). VC999 Bio-Pack is the first producer company that used Ceramis $\AA^{\circledR}$ PLA-SiOx films for meat product packaging in modified atmosphere (MAP) and achieved a shelf life similar to that in packaging of polypropylene (PP) with an oxygen barrier layer of ethylene vinyl alcohol copolymer $(\mathrm{EVOH})(\mathrm{Meyer}$, 2007).

NATIVIA $^{\mathrm{TM}}$ biaxially oriented polylactide (BoPLA) is a new generation of bio-based and compostable packaging films, approved for direct food contact and certified as compostable according to DIN-EN13432. They are foreseen for use with biological products (Taghleef Industries, 2011b). NATIVIA $^{\mathrm{TM}}$ (BoPLA) range includes transparent, metallised, white, and white voided films. They are suitable for a wide range of applications: twist wrap, fresh-produce, bakery, dairy-perishable, confectionery, snacks. Application for confectionery provides optical properties, low sealing temperature, gas barrier, aroma barrier, mechanical properties, dead fold, twistability, and sustainability (Taghleef Industries, 2011a).

Innovia Films Company is a major producer of cellulose and biaxially oriented polypropylene (BOPP). The NatureFlex ${ }^{\mathrm{TM}}$ range of biodegradable cellulose-based films is certified to meet the European EN 13432 and American ASTMS D6400 standards for compostable packaging. The films are advised for packaging of confectionery, bakery goods, and fresh produce. In 2010, Innovia Films Ltd launched a new range of conventional non-perforated breathable, BOPP films (PropaFresh P2G \& P2GAF), which have a polymer formulation for fresh produce packaging (Innovia Films, 2008).

The transparent heat-sealable compostable NatureFlex $^{\mathrm{TM}}$ NVS film has been specifically formulated with an excellent barrier to gases and aromas. The first metallised biodegradable film suitable for both industrial and home composting has been introduced by Innovia Films and certified according to EN13432 and ASTM D6400. The level of metal in it is very small - less than $0.02 \%$, which slows the film's degradation by a matter of days but does not interfere with its biodegradability. Metallised biodegradable NatureFlex NM film by Innovia Films has been launched especially targeting for the confectionery business (Innovia Films, 2006).

Polyhydroxyalkanoates (PHAs) are well known to biodegrade under anaerobic conditions, in contrast with other condensation polymers (including PLA and aliphatic polyesters) that do not biodegrade in the absence of oxygen (Swift \& Wiles, 2004). 
Bioplastics continue to be an exciting area of growth for the plastics industry. The European capacity of bio-based plastics is projected to rise from $0.14 \mathrm{Mt}$ in 2007 to $0.44 \mathrm{Mt}$ in 2013 , and to $1.65 \mathrm{Mt}$ in 2020 , i.e., annual growth rate of $16 \%$ between 2007 and 2020. Today in Europe, $0.27 \mathrm{~kg}$ of bio-based plastics are produced per capita per year, while the yearly per capita production of petrochemical plastics is around $103 \mathrm{~kg}$. Even by 2020, European production of bio-based plastics is projected not to exceed $2 \mathrm{~kg}$ per capita, while petrochemical plastics may amount to $166 \mathrm{~kg}$ per capita (Shen, Haufe, \& Patel, 2009).

The transition from a fossil-based economy to a bio-economy is an important target of the EU 2020 Strategy (European Bioplastics, 2011). The report at the 6th Conference on Industrial Biotechnology and Bio-based Plastics and Composites shows that the production capacities of bio-based polymers will tripple from 3.5 million tonnes in 2011 to nearly 12 million tonnes by 2020 (Carus, 2013).

The object of the present research was, firstly, to draw a general conclusion from the experiments with various kinds of biodegradable and environmentally friendly materials with different barrier properties as an alternative for packaging, storage and quality maintenance of different foods with various typical properties, composition and structure, and, secondly, to compare the obtained results with the influence of conventional packaging materials.

\section{Materials and Methods}

Consumer inquiry. To clarify the situation in Latvia's market, as well as to study the consumer awareness problem and attitude to traditional and biodegradable polymer packaging materials and their implementation in the market at present, a questionnaire was accomplished, involving a total of 1200 respondents (50\% females and 50\% males) from all regions of Latvia (Muizniece-Brasava, Dukalska, \& Kantike, 2011).

Packaging materials applied for the experiments. The most widely used commercially available innovative environmentally friendly materials and conventional packaging materials as control were studied. Seven various kinds of biodegradable and environmentally friendly packaging materials with different barrier properties were used to determine the possible shelf life of investigated products as well as their quality during storage (Dukalska et al., 2012).

NatureWorks $^{\circledR}$ PLA P-360 containers nonhermetically closed with PLA lids, obtained from local packaging material distributors, were used for packaging of shredded carrots in air ambiance.

A plain transparent BIO PLA 121 film (thickness $-30.0 \mathrm{~mm}$ and $40.0 \mathrm{~mm}$ ) with a relatively poor barrier to water vapour, oxygen, and carbon dioxide, which is suited primary for short shelflife applications that use cold-filling techniques (Green \& Kunneman, 2006), was tested for the packaging in air ambiance of fresh cheese, cakes with raisins, and salad with meat and mayonnaise.

The Ceramis ${ }^{\circledR}-\mathbf{P L A}-$ SiOx coated films are the first new biodegradable PLA films with improved barrier properties (Glaw, 2007). This film, with thickness of $50 \pm 2 \mu \mathrm{m}$, was tested for a number of foods: fresh produce shredded carrots and freshcut apple salads in passive modified atmosphere packaging; fresh cheese, rye bread and wheat bread (in MAP, applying oxygen absorber); and milk pomade sweet sherbet, and marmalade for long term storage.

NATIVA $^{\text {TM }}$ NTSS BoPLA films were introduced commercially during the second half of 2010 (Taghleef Industries, 2012). They (thickness: transparent film - $30 \mu \mathrm{m}$; metallised film $-20 \mu \mathrm{m}$ ) were used for packaging of milk pomade sweet sherbet - and for testing of its long-term storage in $100 \% \mathrm{CO}_{2}$ environment.

The cellulose-based, transparent, moisturepermeable NatureFlex ${ }^{\text {TM }}$ NVS Innovia film (thickness $-35 \pm 1 \mu \mathrm{m}$ ) (Innovia Films, n.d.) was used for packaging of fresh produce (shredded carrots, and fresh-cut apple salad) in air ambiance, and one side metallised high barrier NatureFlex ${ }^{\mathrm{TM}}$ 23NM film (thickness $-23 \pm 1 \mu \mathrm{m}$ ) was used for packaging of milk pomade sweet - sherbet - in $100 \% \mathrm{CO}_{2}$ environment.

Ecolean, a milky white film (thickness $75 \pm 2 \mu \mathrm{m})$ (Ecolean, n.d.), was also used for packaging of milk pomade sweet - sherbet - in 100\% $\mathrm{CO}_{2}$ environment.

The poly- $\beta$-hydroxybutyrate (PHB) film with thickness of $75 \pm 2 \mu \mathrm{m}$ (pellets obtained from Brazil; the film moulded at the Riga Technical University) was used for packaging of perishable food - salad with meat and mayonnaise - in vacuum and in Sous vide applying mild thermal treatment regime (Muižniece-Brasava, 2006).

Four types of conventional polymers manufactured from oil-based resources were used as control packaging to draw comparisons with the influence of biodegradable packaging materials on the possible shelf life and quality of foods during the storage time: 
- conventional, non-perforated breathable BOPP Propafilm $^{\text {TM }}$ P2GAF film (thickness $-38 \pm 1 \mu \mathrm{m}$ ) (Innovia Films, 2008) was used for packaging of fresh produce - shredded carrots, and fresh-cut apple salad;

- laminated polyamide/polyethylene (PA/PE) film (thickness - 20/45 $\pm 2 \mu \mathrm{m}$ ) (different-size pouches with barrier properties, suitable for the vacuum and MAP packaging of the most types of foods) was used as control packaging for salad with meat in mayonnaise and for cakes with raisins;

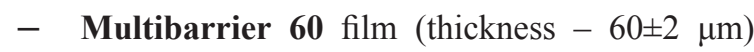
(APA/TIE/PA/EVOH/PA/TIE/PE/PE) with an EVOH oxygen barrier layer was used as control for packaging of different foods;

- DuniForm PP containers $(80 \times 120 \times 42 \mathrm{~mm}$; thickness - 50 $\pm 2 \mu \mathrm{m}$ ) (Duni, 2012) were used for packaging and storage of fresh produce shredded carrots, and fresh-cut apple salad.

All materials used in the experiments were purchased from local food packaging material distributors in Latvia.

Preparation, analyses, packaging, and storage of food samples. Four groups of foods (fresh-cut fruits and vegetables, perishable foods, breadstuffs, and candies) with different physical and chemical properties were tested for the possible shelf life and quality parameters during storage in biodegradable packaging materials in comparison with those of the foods stored in conventional polymer packaging.

\section{Fresh-cut fruits and vegetables}

Shredded carrots. Fresh serotinous 'Nante' cultivar hybrid carrots, locally grown and harvested in Zemgale region and stored for four months at the planter's storehouse at $4 \pm 0.5{ }^{\circ} \mathrm{C}$ and $80 \% \mathrm{RH}$, were used for the experiments. The carrots were washed, manually peeled and shredded into small strips, using the Philips Comfort HR 7605 device. The chemical and physical characteristics of the produce were analyzed before packaging and during storage (Dukalska et al., 2012; Rakcejeva, Augspole, Dukalska, \& Dimins, 2012).

Fresh-cut apple salad. Apples were peeled and cut with a sharp knife into small pieces $(2.0 \times 2.0 \mathrm{~mm})$, and soaked for $3 \mathrm{~min}$ in a $5 \%$ solution of Natureseal®AS5 (AgriCoat Ltd., Great Shefford, United Kingdom) to prevent browning. The prepared apple salad was packaged in DuniForm PP containers, $180 \pm 5 \mathrm{~g}$ in each. The containers were sealed in air ambiance for passive modified atmosphere formation during storage. The quality of salad was evaluated by its physicochemical properties (Krasnova et al., 2012; Krasnova, Karklina, Seglina, Juhnevica, \& Kviesis, 2011).

\section{Perishable foods}

Salad with meat in mayonnaise. The potential shelf life of salad (produced by VSL Pārtikas grupa in Latvia) packaged in vacuum and in Sous vide in conventional $\mathrm{PA} / \mathrm{PE}$ film pouches (control) and in experimental biodegradable PLA and PHB film pouches was assessed by its microbiological quality. Sous vide packaging was provided by mild thermal treatment in a water bath at the temperature of $+65.0 \pm 0.5{ }^{\circ} \mathrm{C}$. The samples were stored in the commercial freezer/cooler "Elcold" at the temperature of $4.0 \pm 0.5{ }^{\circ} \mathrm{C}$ till 52 days, and analysed after each four storage days (Dukaļska, Muižniece-Brasava, \& Levkāne, 2008; Levkane, 2011; Levkāne, Levkāne, Dukaļska, \& Muižniece-Brasava, 2010).

Soft cheese Kleo (produced in Latvia). Cheese samples were packaged in biodegradable PLA film without barrier properties and in Ceramis ${ }^{\circledR}$ PLA-SiOx film with barrier properties in modified atmosphere (MAP). The influence of both packaging materials on the product's shelf life was investigated in comparison with the influence of some conventional polymer films. The modified atmosphere consisted of $30 \% \quad \mathrm{CO}_{2} \quad$ (E 290) and $70 \% \quad \mathrm{~N}_{2}$ (E 941). The analyzable samples were stored at the temperature of $+4.0 \pm 0.5^{\circ} \mathrm{C}$ up to 32 days (Dukalska et al., 2011; Muizniece-Brasava, Dukalska, Murniece et al., 2011).

\section{Breadstuffs}

Packaging of rye bread. Up to now, biomaterials as bread packaging have been relatively little investigated. The aim of the present research was to study an innovative solution using the biodegradable Ceramis ${ }^{\circledR P L A-S i O x}$ coated packaging film in combination with iron-based oxygen absorber sachets (obtained from Mitsubishi Gas Chemical Europe Ageless $^{\circledR}$ ) incorporated into the pouches with bread as well as to compare it with the impact of the conventional Multibarrier 60 laminate film by controlling the dynamics of moisture content and hardness of bread (Muizniece-Brasava et al., 2012). The samples were packaged in polymer pouches, hermetically sealed in air ambience with the MULTIVAC C300 vacuum chamber machine, and stored at room temperature of $21.0 \pm 1.0{ }^{\circ} \mathrm{C}$ up to 
28 days under the day and night lighting. Two slices of rye bread (on average $120 \times 80 \times 15 \mathrm{~mm}$; mass $50 \pm 3 \mathrm{~g}$ ) were placed in each package. Size of each pouch was $200 \times 150 \mathrm{~mm}$; total mass of the product in each package $-100 \pm 6 \mathrm{~g}$. The samples were analyzed before packaging and on the 7th, 14th, 21st and 28th day of storage.

Packaging of wheat bread. Wheat bread was placed in biodegradable Ceramis ${ }^{\circledR}$ PLA-SiOx film pouches in modified atmosphere (MAP consisting of $\mathrm{CO}_{2} 60 \%$ and $\mathrm{N}_{2} 40 \%$ ) combined with oxygen scavengers (active packaging), and the pouches were hermetically sealed. Packaging in air ambience was performed in traditional polymer Multibarrier 60, PP and OPP pouches (Muizniece-Brasava et al., 2012).

Packaging and storage of cakes with raisins. The effectiveness of a plain PLA film without barrier properties was studied for the packaging and storage in vacuum of cakes with raisins produced in Latvia. The changes in hardening and the reduction in moisture content were chosen as the main characterising parameters of the product during storage (MuiznieceBrasava, Saulite, Dukalska, \& Straumite, 2007).

\section{Confectionery}

Milk pomade sweet - sherbet. Five biodegradable films (NatureFlex NVS, Ceramis ${ }^{\circledR}$ PLA-SiOx, Nature Flex 23NM, 6 NativiaTM NTSS30, and Nativia NZSS-20), as well as environmentally friendly Ecolean film was used for a long term storage of sherbet in $100 \% \mathrm{CO}_{2}$ gas ambiance. The results were compared with the influence of high barrier Multibarrier 60 film (control) on the main characteristic property of sherbet - change in hardness during storage, expressed by cutting force (Vorma, Muizniece-Brasava, Dukalska, \& Skalbe, 2010).

Apple-black currant marmalade candies. Oxygen absorbers (active packaging) in combination with modified atmosphere (MAP, $100 \% \mathrm{CO}_{2}$ ) were examined and compared with traditional packaging in air ambiance; polymer Multibarrier 60 was used as control. The influence of iron-based oxygen absorber in sachets of $500 \mathrm{cc}$, obtained from Mitsubishi Gas Chemical Europe Ageless ${ }^{\circledR}$, was tested on the quality of marmalade candies during the product's shelf life (Muizniece-Brasava, Dukalska, Kampuse et al., 2011).

Microbiological analyses. The samples were prepared according to the LVS EN ISO 6887-5:2011 standard. The obtained microbial count values were expressed as colony forming units $\left(\mathrm{CFU} \mathrm{\textrm {g } ^ { - 1 }}\right)$ and determined according to LVS EN 4833:2003. Yeasts and moulds were determined according to LVS ISO 21527:2003.

Statistical analyses. The results were processed by mathematical and statistical methods. Statistics of a completely randomized design were determined using the General Linear Model (GLM) procedure SPSS, version 16.00. Two-way analyses of variance $(p \leq 0.05)$ were used to determine the significance of differences between various parameters determined in the experiments.

\section{Results and Discussion}

Consumer attitude to application of biopolymers for food packaging varies (Arvanitoyannis \& Kasaveti, 2008). Most of consumers consider that conventional polymers are overly applied in food product packaging, $82 \%$ of respondents support the idea of implementing new, eco-friendly food packaging materials, and only a small part (5 to $10 \%$ ) agree to pay more for biopolymer packaging materials to protect the environment. Out of all the consumers, approximately $25 \%$ are unwilling to pay more, and only $1 \%$ agree to pay for environmentally friendly packaging twice as much as for conventional packaging (Muizniece-Brasava, 2011). To optimize the environment protection effects of food packaging, it is essential to educate consumers and to analyse the system that covers its main purpose - food (Dukalska et al., 2012).

Packaging and storage of fresh produce. Fresh fruit salad and shredded carrots have become increasingly popular, but their sales are restricted due to their rapid deterioration during storage (Barry-Ryan, Pacussi, \& O'Beirne, 2000; Rakcejeva, Augspole, Dukalska, \& Dimins, 2012). Extensive experiments on the chemical and physical composition and properties of Latvia-grown fruits and their salads have been carried out at the Latvia State Institute of Fruit Growing (Krasnova et al., 2012; Krasnova, Karklina, Seglina, Juhnevica, \& Kviesis, 2011).

In the present research, the quality of both investigated fresh products - shredded carrots and fresh-cut fruit salad - during storage in different biodegradable packaging materials (Ceramis ${ }^{\circledR}-P L A-$ SiOx coated, and NatureFlexTMNVS Innovia Films) was compared with the results obtained from the same products stored in conventional breathable BOPP Propafilm ${ }^{\mathrm{TM}} \mathrm{P} 2 \mathrm{GAF}$ packaging used as control. The main target was to evaluate the capability of both films to form a passive equilibrium modified atmosphere 


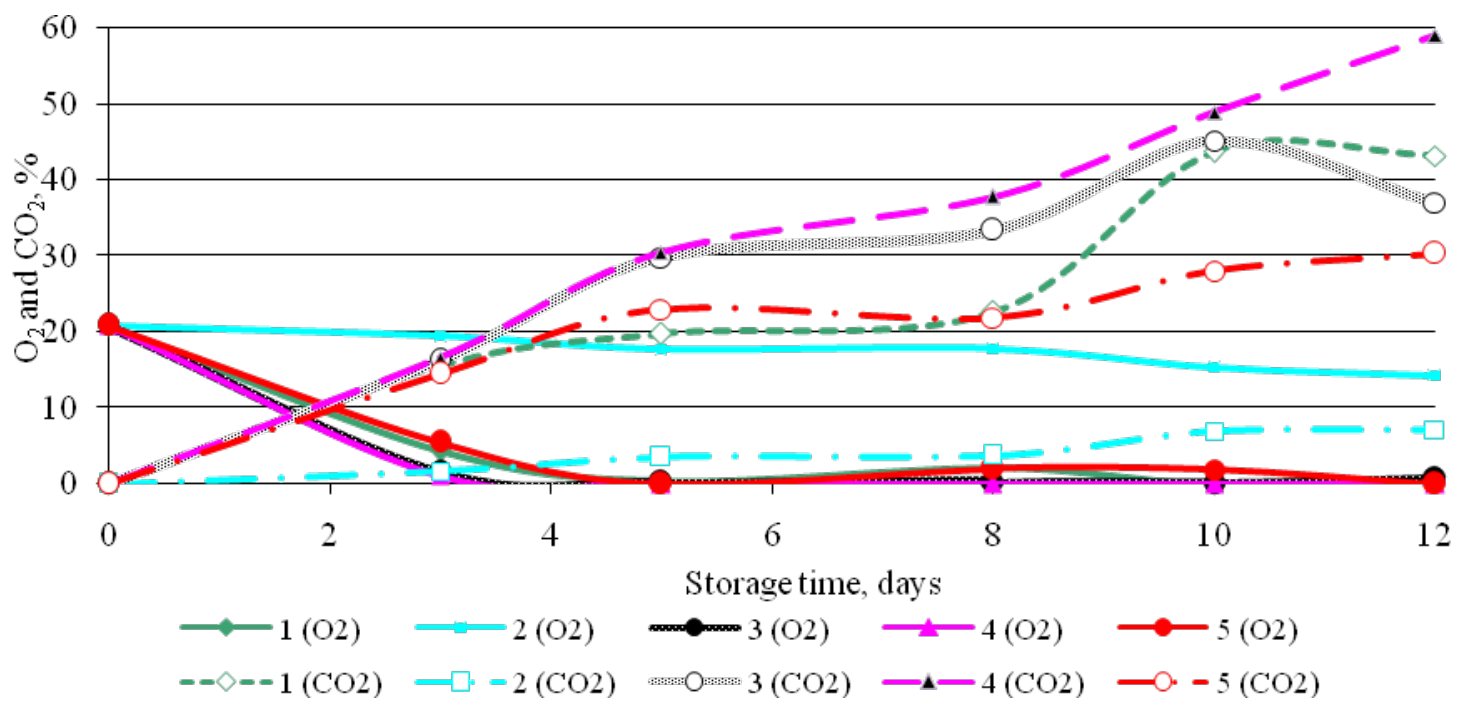

1- BOPP Propafilm ${ }^{\mathrm{TM}}$ P2GAF film (control); 2 - Bio-PLA containers; 3 - PLA plain film;

4 - Ceramis ${ }^{\circledR}$-PLA film; 5 - NatureFlex NVS film

Fig. 1. The influence of different biodegradable films on the passive EMAF formation in packaging of shredded carrots.

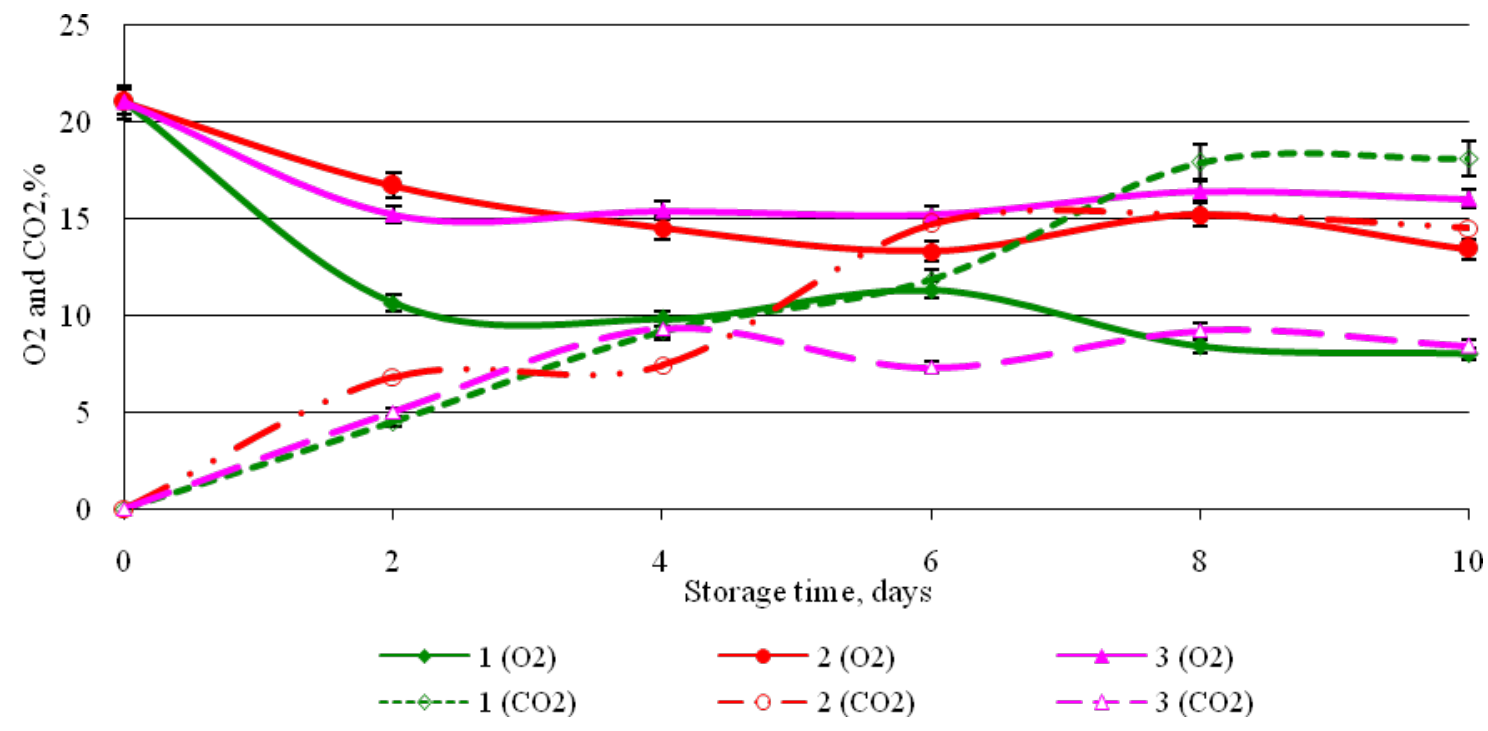

1 - BOPP Propafilm ${ }^{\mathrm{TM}}$ P2GAF (control); 2 - Nature Flex ${ }^{\mathrm{TM}} \mathrm{NVS} ; 3$ - Ceramis $^{\circledR}$ PLA film

Fig. 2. The influence of different biodegradable films on the passive EMAF formation in packaging of fresh-cut apple salad.

(PEMA) in the packaging of fresh-shredded carrots (Fig. 1) and fresh-cut apple salad (Fig. 2) during the storage time.

Observations prove that both conventional breathable and biodegradable films with an appropriate oxygen transmission rate (OTR) play an important role in developing an equilibrium modified atmosphere (EMA) and in involving quality maintenance in packages of fresh-cut produce during storage (Augspole, Dukalska, Rakcejeva,
Muizniece-Brasava, \& Sabovics, 2012). The passive EMAP composition in the headspace of packs during storage time changed, and the increase in $\mathrm{CO}_{2}$ and the decrease in $\mathrm{O}_{2}$ were miscellaneous depending on barrier properties of the used films.

In both experiments of fresh produce packaging in three identical films, the results of gas composition formed during storage were different. Following the storage time during 10 days, the $\mathrm{CO}_{2}$ content in carrots packaged in NatureFlex ${ }^{\mathrm{TM}}$ NVS Innovia film 
was $28 \%$, whereas in fresh-cut apple salad packaged in the same film - 15\%. Interesting results were observed in Ceramis ${ }^{\circledR}-\mathrm{PLA}-\mathrm{SiOx}$ film packaging: $\mathrm{CO}_{2}$ content approached $50 \%$ in shredded carrots, but in fresh salad - only $17 \%$. An analogical difference was observed in the control BOPP Propafilm ${ }^{\mathrm{TM}}$ P2GAF film packaging: In carrot pack headspace, the $\mathrm{CO}_{2}$ content was $44 \%$, but in fresh fruit salad packs - only $18 \%$. This could be attributed to a higher respiration rate of shredded carrots, which before packaging were not treated with any antibrowning agent, whereas fresh-cut apple pieces were disinfected against browning with Natureseal ${ }^{\circledR}$ AS5, which limits the respiration rate and increase in $\mathrm{CO}_{2}$. In non-hermetically closed BioPLA containers, the $\mathrm{CO}_{2}$ concentration increased only up to $7-8 \%$.

The oxygen content (in air ambiance - $21 \%$ ) in all fresh produce packaging decreased as a result of the product respiration. The decrease in $\mathrm{O}_{2}$ content and the corresponding gas composition in various kinds of packaging were disparate. In non-hermetically sealed Bio-PLA containers with shredded carrots, the decrease in $\mathrm{O}_{2}$ was the least $-14 \%$ at the end of 12 storage days; in packaging of all other materials (including control), the $\mathrm{O}_{2}$ concentration decreased very fast and already after five storage days was close to zero, once more proving the fact that respiration proceeds very intensively in small-strips-shredded carrots without any treatment.

After 10-day storage of fresh-cut fruit salad, proportionally to increase in $\mathrm{CO}_{2}$ levels, the decrease in $\mathrm{O}_{2}$ content in containers sealed with the BOPP Propafresh $^{\mathrm{TM}}$ P2GAF film was $8 \%$; in NatureFlex ${ }^{\mathrm{TM}}$ NVS Innovia Film pouches - 13\%; and in Ceramis ${ }^{\circledR}$ PLA-SiOx film pouches $-16 \%$.

The equilibrium between $\mathrm{O}_{2}$ and $\mathrm{CO}_{2}$ was reached within 10 storage days in NatureFlex ${ }^{\mathrm{TM}} \mathrm{NVS}$ Innovia Film packaging; also in Ceramis ${ }^{\circledR}$-PLA-SiOx film pouches, the gas composition demonstrated satisfactory results. As a result, quite good textural, aroma, flavour and microbial characteristics of the tested fruit salads were retained. Evaluation of biodegradable packaging for shredded carrots showed that the best variant was the elementary packaging form - Bio PLA containers with nonhermetically pressed lids -, in which at the end of the experiment, the passive EMAP, which is closer to ideal atmosphere composition (i.e., $\mathrm{CO}_{2}-5-10 \%$, and $\mathrm{O}_{2}-5-10 \%$ ), was achieved.

The different changes in the $\mathrm{O}_{2}$ and $\mathrm{CO}_{2}$ content in both kinds of biodegradable packaging of experimentally tested fresh produce might be explained by the different structure and chemical composition of the packaged products, size of the cut sample pieces, treatment of the produce before packaging, as well as other conditions. This means that usefulness of any biodegradable material for packaging of fresh-cut produce should be verified by its users in production conditions.

Mass loss of apple salad packaged in Ceramis ${ }^{\circledR}$ PLA-SiOx film during 10 storage days was insignificant $(<0.46 \%)$, whereas of shredded carrots in the same packaging it was noticeably high (4.7\%) even after 12-day storage. Mass loss of both investigated kinds of fresh produce packaged in Nature Flex ${ }^{\mathrm{TM}}$ NVS and BOPP Propafilm ${ }^{\mathrm{TM}} \mathrm{P} 2 \mathrm{GAF}$ was insignificant $-0.15-0.50 \%$. Similar mass losses have been reported by Rocha and Morais (2003): $0.22 \%$ in fresh-cut apples packaged in air ambiance and stored at $4{ }^{\circ} \mathrm{C}$ for 10 days.

The influence of packaging on the firmness of fresh-cut fruit salad and shredded carrots is shown in Figs 3 and 4. During storage of 10-12 days, firmness reduced gradually. The firmness of fresh-cut apple pieces before packaging was $18.3 \pm 2.0 \mathrm{~N}$, which reduced to $16.2 \pm 2.0 \mathrm{~N}$ in the control packaging of BOPP Propafilm ${ }^{\mathrm{TM}}$ P2GAF film, but in the Ceramis ${ }^{\circledR}$ PLASiOx film packaging - to $17.2 \pm 2.0 \mathrm{~N}$. The difference in the influence of various packaging materials on the firmness of fruit salad was insignificant $(p>0.05)$ and was evaluated as good when stored for up to 10 days.

The research showed that for fresh-cut apple salad, the most appropriate was cellulose-based biodegradable NatureFlex ${ }^{\mathrm{TM}}$ NVS Innovia film packaging; also packaging in Ceramis ${ }^{\circledR}$-PLA-SiOx film pouches demonstrated satisfactory results.

The initial firmness of shredded carrots $450.0 \pm 10 \mathrm{~N}$ - decreased differently in various packaging materials. Considerably differed the PLA plane film influence reducing the firmness of shredded carrots to $80.0 \pm 5.0 \mathrm{~N}$, at which the carrots were spoiled. The least decrease in the product's firmness was observed in cellulose-based biodegradable NatureFlex NVS film packaging - to $320 \pm 10 \mathrm{~N}$, but in all other materials - to $240 \pm 10 \mathrm{~N}$. The results showed that the quality of carrots was acceptable for up to 10 days of cold storage.

Growth of total plate count (TPC) in freshcut apple salad during storage substantially depended on the packaging method, material, 


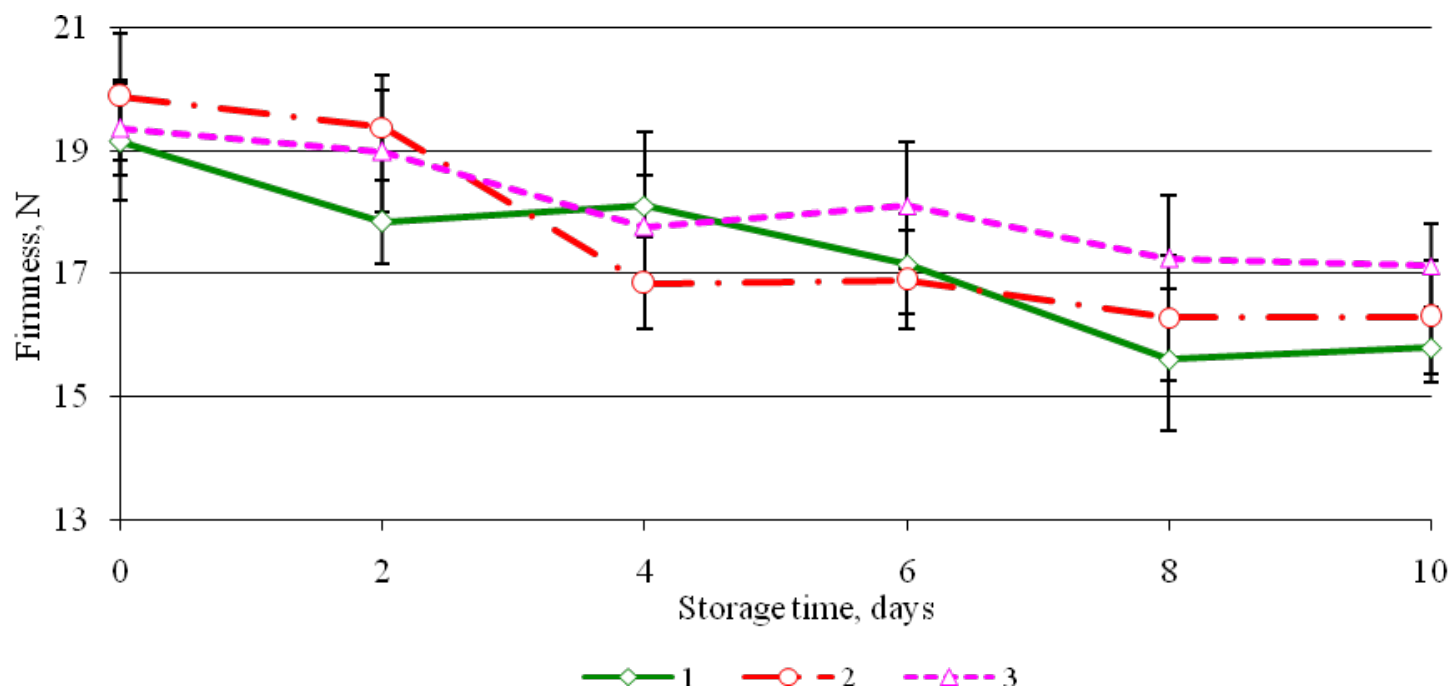

1 - BOPP Propafilm ${ }^{\mathrm{TM}}$ P2GAF film (control); 2 - Nature Flex ${ }^{\mathrm{TM}}$ NVS film; 3 - CERAMIS ${ }^{\circledR}$ PLA-SiOx film

Fig. 3. The influence of different biodegradable films on the changes in firmness of fresh-cut apple salad.

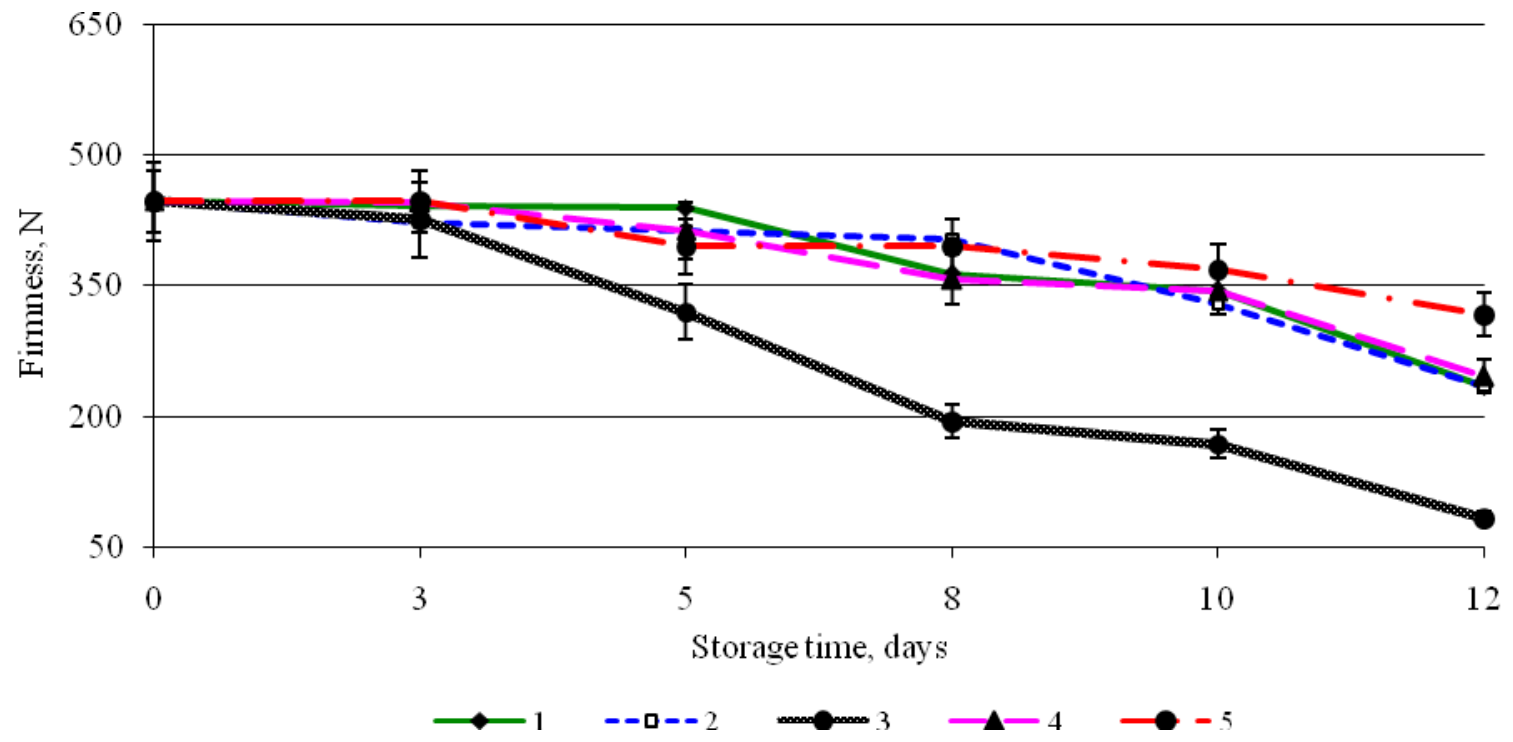

1 - BOPP film (control); 2 - Bio-PLA containers; 3 - PLA plain film;

4 - Ceramis ${ }^{\circledR}$ PLA-SiOx film; 5 - NatureFlex NVS film

Fig. 4. The influence of different biodegradable films on the firmness of shredded carrots.

and storage duration $(p<0.05)$. Its increase in biodegradable packaging during storage was from 1.5-2.0 $\log \mathrm{cfu} \mathrm{g}^{-1}$ before packaging to 2.8-3.2 $\log \mathrm{g}^{-1}$ after 10 storage days. It was determined that TPC in fresh-cut apple salad in biodegradable packaging was lower than in conventional polymer packaging (Krasnova et al., 2012).

Perishable foods - packaging and storage. Mayonnaise-based salads are perishable products belonging to a high-risk food group (Biedrïba ..., 2006). It is essential to evaluate the quality of the products under the microbiological criteria recommended by Latvia's Food and Veterinary Service (FVS), whereabouts the total plate count (TPC) of microorganisms could be $\mathrm{N} \leq 10^{5}$ cfu $\mathrm{g}^{-1}$, which in comparison with the microbiological quality parameters $\left(\mathrm{N} \leq 10^{7} \mathrm{cfu} \mathrm{g}^{-1}\right)$ of the present guidelines is more limited (Biedrība ..., 2006; Marčenkova, 2010). 


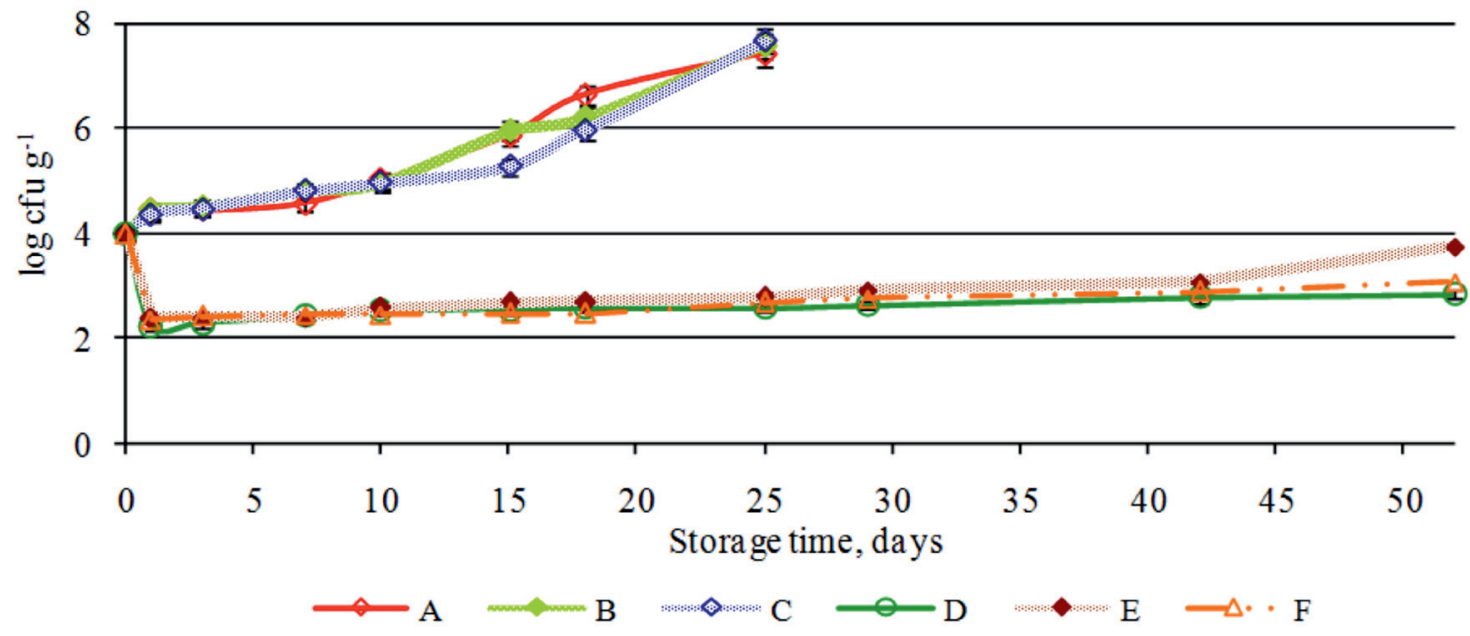

A - PA/PE, vacuum (control); B - PLA, vacuum; C - PHB, vacuum; D - PA/PE, Sous vide;

$\mathrm{E}$ - PLA, Sous vide; F - PHB, Sous vide

Fig. 5. The dynamics of TPC in Sous vide-packaged salad during thermal treatment process and storage time at the temperature of $+4.0 \pm 0.5^{\circ} \mathrm{C}$.

The dynamics of TPC in the mayonnaise-based salad with meat during the cold storage in vacuum and in Sous vide packaging till 52 days is shown in Figure 5. Before thermal treatment, the TPC was $1.00 \times 10^{4} \mathrm{cfu} \mathrm{g}^{-1}$, but after the Sous vide thermal treatment it reduced to $1.58 \times 10^{2} \mathrm{cfu} \mathrm{g}^{-1}$ (Dukalska, Muižniece-Brasava, \& Levkāne, 2008; Levkane, 2011; Levkane, Muizniece-Brasava, \& Dukalska, 2008, 2010; Levkāne, Levkāne, Dukalskka, \& Muižniece-Brasava, 2010).

Evaluating the microbiological quality of salads in vacuum and in Sous vide packaging in two biodegradable materials (PLA and PHB), as well as in the control sample in PA/PE packaging, it was established that according to the criteria recommended by the FVS, the maximum acceptable TPC amount $\left(\mathrm{N} \leq 10^{5} \mathrm{CFU} \mathrm{\textrm {g } ^ { - 1 } )}\right.$ in all packaging materials was reached after 10 storage days in vacuum, whereas in Sous vide, the TPC amount was acceptable even after 52 days of storage. A significant difference in the influence of vacuum and Sous vide packaging on the TPC growth was observed $(p<0.05)$. On the other hand, evaluating all salad samples in compliance with the current guidelines ( $\mathrm{TPC}-\mathrm{N}<10^{7} \mathrm{cfu} \mathrm{g}^{-1}$ ), the experimental data were quite different $(p \leq 0.05)$. The shelf life of all salad samples packaged in vacuum was more extended - till 20-22 days.

It was detected that after the first 10 storage days, TPC in Sous vide packaged samples changed insignificantly ( $p=0.318)$, but after 52 days, TPC in sample F (PHB) of Sous vide packaging significantly differed from that in samples D (control) and E (PLA) $(p=0.003)$. The research proved that mayonnaisebased salad with meat packaged in PLA and PHB films in Sous vide can be stored up to 52 days at the temperature of $4.0 \pm 0.5{ }^{\circ} \mathrm{C}$. During this period, the TPC according to the FVS recommended criteria did not reach the maximum limits $\left(\mathrm{N}<10^{5} \mathrm{cfu}^{-1}\right)$ (Levkane, Muizniece-Brasava, \& Dukalska, 2008; 2010; Levkane, 2011). The experiments showed that biodegradable PLA and PHB packaging films can be used even for Sous vide packaging using a mild thermal treatment regime.

Soft cheeses belong to perishable foods, too. Ceramis ${ }^{\circledR}-\mathrm{PLA}-\mathrm{SiOx}$ and plain polylactide PLA films were used for packaging of the soft cheese Kleo. Considering all experimentally obtained results, it was recognized that the shelf life of cheese Kleo could be acceptable when packaged in the biodegradable Ceramis ${ }^{\circledR}-\mathrm{PLA}-\mathrm{SiOx}$-coated film and stored till 30 days, which is similar to conventional packaging materials PE/OPA and Multibarrier 60. Whereas the PLA film, which is without barrier properties, provided the shelf life of only 10 days for the soft cheese Kleo, therefore it can be concluded that the PLA material is not useful for packaging of perishable products (Dukalska et al., 2011). Experiments were also carried out to use the Ceramis ${ }^{\circledR}-\mathrm{PLA}-\mathrm{SiOx}$ for Sous vide packaging of soft cheese Kleo under conditions of mild thermal treatment $\left(60-62{ }^{\circ} \mathrm{C}\right)$, and it was found that the shelf life of cheese Kleo exceeded 30 days.

Breadstuffs - packaging and storage. One of the research objects was rye bread produced in 
Latvia. The initial moisture content of rye bread was $38.96 \pm 0.10 \%$, which decreased diversely in various kinds of packaging during 28 storage days, depending on water vapour permeability of the particular material and on the presence or absence of oxygen absorber. A significant difference $(p<0.05)$ in the moisture content values was found at the end of storage. The moisture content in the bread packaged in Ceramis ${ }^{\circledR}$ PLA-SiOx-coated film pouches with incorporated $\mathrm{O}_{2}$ scavenger diminished most - to $26.0 \pm 0.5 \%$-, while in pouches without oxygen scavenger, the moisture content decreased less - to $29 \pm 0.5 \%$.

The initial hardness of rye bread samples was $49.5 \pm 10.0$ N. During the same storage time, rye bread hardened differently according to significant differences in moisture content values. Hardness of bread in Ceramis ${ }^{\circledR}-\mathrm{PLA}-\mathrm{SiOx}$ coated pouches with incorporated $\mathrm{O}_{2}$ scavenger increased to $245.0 \pm 10.0 \%$, and without $\mathrm{O}_{2}$ scavenger - to $225.0 \pm 10.0 \%$.

During storage, rye bread hardened least in Multibarrier 60 packaging in air ambiance. The results demonstrated that oxygen scavenger application is an effective method to prevent microbial growth during storage; however, it promotes moisture migration through the film.

The biodegradable Ceramis ${ }^{\circledR} \quad$ PLA-SiOx film was applicable for rye bread packaging in air ambiance and for storage of up to 28 days; besides, the results showed that oxygen scavenger application is not recommendable since it promotes moisture migration through the film. The Multibarier 60 film demonstrated better results because of a lower moisture loss and, correspondingly, less hardening and better mouth feel.

The experiments of sliced wheat bread packaging using oxygen absorbers (active packaging) in different polymer materials have been carried out (Muizniece-Brasava et al., 2012). The initial moisture content of wheat bread was $33.81 \pm 0.10 \%$. Application of Ceramis ${ }^{\circledR}-\mathrm{PLA}-\mathrm{SiOx}$ film in MAP $\left(60 \% \quad \mathrm{CO}_{2}\right.$, and $\left.40 \% \mathrm{~N}_{2}\right)$ with and without oxygen absorber was tested. The moisture decrease in bread in both packaging solutions in Ceramis ${ }^{\circledR} \quad$ PLA-SiOx film during 28 days storage was remarkable - to $25.0 \pm 0.6 \%$, while in the Multibarrier 60 film in the same conditions - only to $32.0 \pm 0.2 \%$. At the end of storage, no significant differences $(p>0.05)$ in moisture content values were found among the wheat bread samples packaged in Ceramis ${ }^{\circledR}-\mathrm{PLA}-\mathrm{SiOx}$ film both with and without incorporated oxygen scavengers. It can be concluded that for wheat bread, to maintain an acceptable moisture content, Ceramis ${ }^{\circledR}-\mathrm{PLA}-\mathrm{SiOx}$ film can be used only for a short-term storage, i.e., up to 5-6 days.

The effect of the plain biodegradable PLA film (thickness $40 \mathrm{~m} \mu$ ) on the quality of cakes with raisins within storage time was determined and compared with the effect of the laminated PA/PE film (thickness 20/45 $\mathrm{m \mu}$ ) as control. The hardness of cakes packaged in vacuum in the PLA film increased already after 16 storage days - from $20 \mathrm{~N}$ before packaging to $58 \mathrm{~N}$, and after 43 days - up to $158 \mathrm{~N}$; whereas in the samples packaged in the PA/PE film during the same storage time - only up to $40 \mathrm{~N}$. The moisture content in vacuum-packaged cakes in the biodegradable PLA film decreased to $17 \%$ very rapidly, while in the $\mathrm{PA} / \mathrm{PE}$ film, it remained constant, i.e. $33 \%$, during the 43 storage days. The research results demonstrated that the plain PLA film is not applicable for packaging of cakes with raisins (Muizniece-Brasava, Saulite, Dukalska, \& Straumite, 2007).

Candies - packaging and storage. Milk pomade sweet - sherbet - is one of the most popular delicious sweets in Latvia (Ungure, Muizniece-Brasava, \& Dukalska, 2011). Packaging films with high moisture barrier properties could be a common practice. A preliminary investigation on the evolution of the texture of freshly manufactured sherbet packaged in various plastic films with several barrier properties has been carried out (Ungure, Muizniece-Brasava, Dukalska, \& Levkane, 2012; Vorma, MuiznieceBrasava, Dukalska, \& Skalbe, 2010).

Although biodegradable films currently do not have sufficiently good barrier properties, our experiments were performed to check the adequacy of several biopolymers for packaging and shelf life determination of the specific milk pomade sweet sherbet. Five biodegradable and one environmentally friendly (Ecolean) packaging material were used for long-term storage of sherbet in $100 \% \mathrm{CO}_{2}$ gas ambiance. The obtained results were compared with the influence of the Multibarrier 60 film with high barrier properties on the most important property of sherbet - hardness, expressed in cutting force.

During storage, the product's hardness changed disparately $(p<0.05)$ in various biodegradable materials in air ambiance (Fig. 6). The difference was observed already after two weeks of storage. Evaluating the quality of sherbet following the respondents' recognized mouth feel, the product could be considered usable for consumption when its hardness did not exceed $300 \mathrm{~N}$. The hardness of 


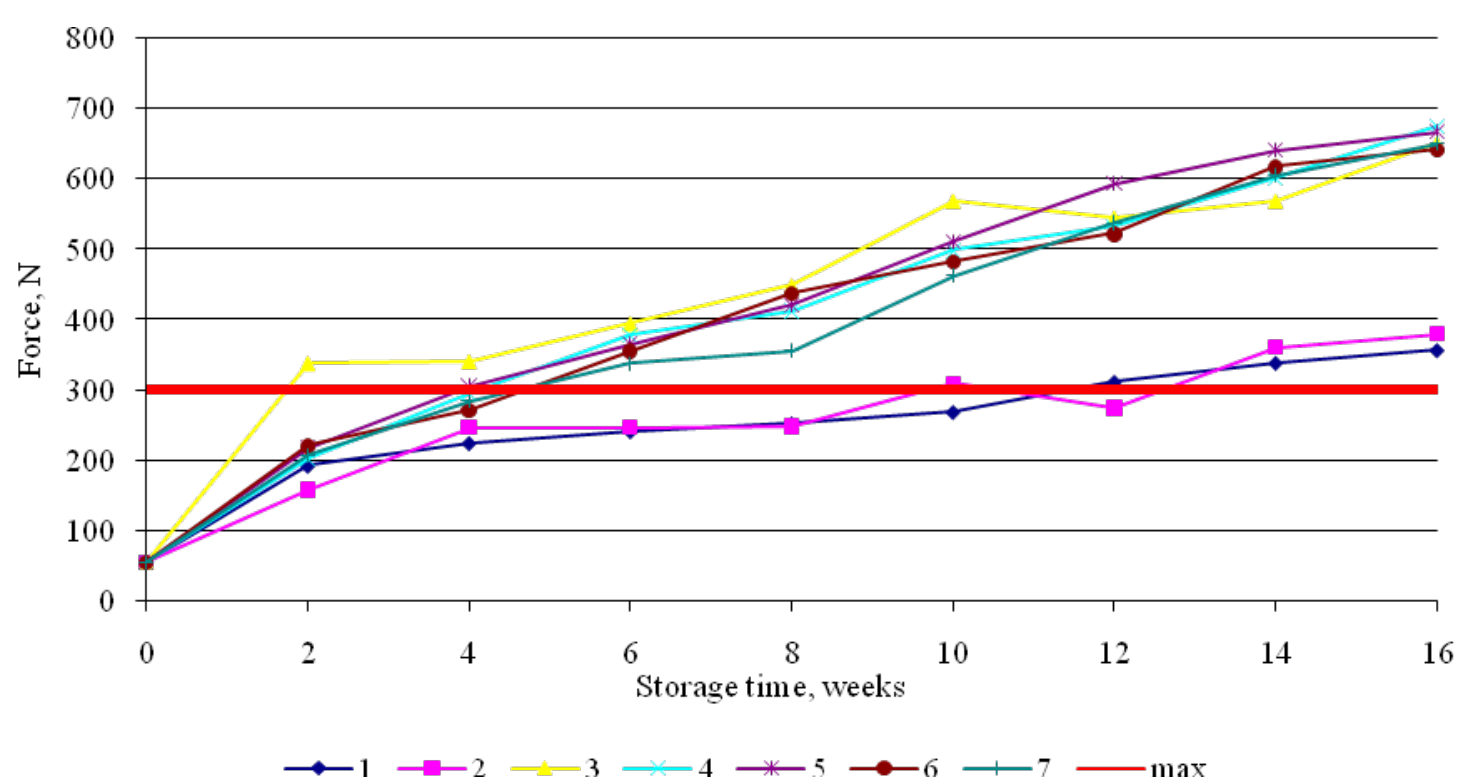

- - sensory estimated maximum hardness level $300 \mathrm{~N}$

1 - Multibarrier 60 HFP (control); 2 - Ecolean; 3 - NatureFlex NVS; 4 - Ceramis ${ }^{\circledR}-P L A-S i O x ;$

5 - Nature Flex 23NM; 6 - NativiaTM NTSS-30; 7 - Nativia NZSS-20

Fig. 6. The dynamics of changes in sherbet hardness during storage.

samples packaged in NatureFlex NVS film in air ambiance increased up to $338.0 \pm 5.0 \mathrm{~N}$ already after a two-week storage, surpassing the limit set by the respondents. A conclusion was made that a cellulosebased biodegradable material as sherbet packaging can be used only for short-term storage (6-7 days).

The sherbet packaged in the environmentally friendly Ecolean and Multibarrier 60 HFP (control) films, in its turn, was acceptable even within 12 storage weeks - its hardness did not exceed $300 \mathrm{~N}$.

The quality of samples packaged in NatureFlex NVS film was acceptable only within two weeks storage, while in the rest four investigated biodegradable packaging materials (Ceramis ${ }^{\circledR}-\mathrm{PLA}$ SiOx, Nature Flex 23NM, Nativia ${ }^{\mathrm{TM}}$ NTSS-30, and Nativia NZSS-20), the hardness of sherbet increased up to $300.0 \pm 5.0 \mathrm{~N}$ within a longer time - six weeks. This could be explained by the presence of oxygen in air ambience packaging, which promotes moisture migration through the films, at the same time increasing the hardening rate of sherbet.

The quality of sherbet packaged in $\mathrm{CO}_{2}$ atmosphere in Multibarrier 60 film was acceptable within 16 storage weeks. It can be concluded that barrier properties of investigated biodegradable packaging materials do not allow their use for longterm storage of such untraditional confection as sherbet. The highest mass loss was observed in the sherbet packaged in NatureFlex NVS film - 5.3\%, then follows Multibarrier 60 film $-1.8 \%$, but the lowest mass loss was in Ecolean packaging $-1.3 \%$. In all other kinds of packaging, losses in sherbet mass during 16 weeks of storage were similar - between $3.0-3.2 \%$.

Apple-black currant marmalade candies packaging and storage. The Ceramis ${ }^{\circledR}$-PLASiOx film with high barrier properties was also investigated to determine the shelf life of appleblack currant marmalade candies. Evaluation of the product's hardness showed that the best packaging for marmalade candies was the transparent Multibarrier 60 film: After 15 weeks of storage, the initial cutting force of the product insignificantly increased from $1.38 \pm 0.02 \mathrm{~N}$ to $1.68 \pm 0.03 \mathrm{~N}$. At the same time, in Ceramis ${ }^{\circledR}$ PLA-SiOx film packaging, the increase in hardness was somewhat higher up to $2.60 \pm 0.05 \mathrm{~N}$.

The research showed that packaging of biodegradable Ceramis ${ }^{\circledR}-P L A-S i O x$ film could maintain the quality of apple-black currant marmalade candies for only up to 8 storage weeks, therefore Multibarier 60 (MAP, $100 \% \mathrm{CO}_{2}$ ) film packaging with an incorporated oxygen scavenger can be considered the best variant (MuiznieceBrasava, Dukalska, Kampuse et al., 2011). 


\section{Conclusions}

The different changes in gas composition $\left(\mathrm{O}_{2}\right.$ and $\mathrm{CO}_{2}$ ) in pouches of two experimentally examined biodegradable packaging materials (Ceramis ${ }^{\circledR}$ PLA-SiOx coated and NatureFlexTM NVS Innovia Films) for fresh produce - fresh-cut apple salad and shredded carrots - could be explained by the various structure, chemical composition, and size of the cut sample pieces, treatment before packaging, and other conditions. Nature Works ${ }^{\circledR}$ PLA P-360 containers can be suggested as a cheapest variant for successful packaging and storage of shredded carrots for up to 7-8 days. Comfortable PEMA conditions were established in the biodegradable Ceramis ${ }^{\circledR}-\mathrm{PLA}-\mathrm{SiOx}$ and NatureFlex ${ }^{\mathrm{TM}}$ NVS Innovia Films packaging, as well as in conventional breathable BOPP Propafresh ${ }^{\mathrm{TM}}$ P2GAF (control) film ensuring the quality of products for up to $7-8$ days.

It was experimentally determined that biodegradable Ceramis ${ }^{\circledR}-\mathrm{PLA}-\mathrm{SiOx}$ coated film as well as PLA and PHB films can be used even for Sous vide packaging of some foods when mild thermal treatment regime was applied.

The biodegradable Ceramis $\AA-P L A-S i O x$ film was applicable for packaging of rye bread in air ambiance and for storage of up to 28 days. The experiments demonstrated that oxygen scavenger application is not recommendable as it promotes moisture migration through the film. The Multibarier 60 film showed better results for rye bread samples, i.e., lower moisture losses and correspondingly less hardening and better mouth feel.

It was determined that the highest hardness value in milk pomade sweet - sherbet - by mouth feel was $300.0 \pm 5.0 \mathrm{~N}$. Packaging of cellulosebased biodegradable film Nature Flex 23NM in air ambiance could be used only for a shortterm storage of sherbet, i.e., up to 6-7 days. The shelf life of the sherbet packaged in $\mathrm{CO}_{2} 100 \%$ environment in Ceramis ${ }^{\circledR}$ PLA-SiOx, NativiaTM NTSS-30 and Nativia NZSS-20 films did not exceed six weeks, whereas the sherbet packaged in the environmentally friendly Ecolean and conventional Multibarrier 60 HFP (control) films was acceptable within 12 storage weeks.

The results demonstrated that biodegradable packaging materials can be a successful alternative to the conventional polymers for packaging of fresh-cut produce, and they can offer essential contribution to the reduction of environmental pollution. Ceramis ${ }^{\circledR}-\mathrm{PLA}-\mathrm{SiOx}$ with high barrier properties can be widely applied for food packaging, providing individual approach for each specific instance.

\section{References}

1. Arvanitoyannis, I.S., \& Kasaveti, A. (2008). Consumer attitude to food packaging, and the market for environmentally compatible products. In E. Chielliny (Ed.), Environmentally compatible food packaging (pp. 161-181). Cambridge, England: Woodhead Publishing Ltd.

2. Augspole, I., Dukalska, L., Rakcejeva, T., Muizniece-Brasava, S., \& Sabovics, M. (2012). Physicochemical quality evalution of feesh-cut carrots packed and stored in biodegradable film packaging. In Proceedings of 18th International Conference for Renewable Resources and Plant Biotechnology, NAROSSA, 4-5 June 2012 [CD]. Magdeburg, Germany.

3. Auras, R., Harte, B., \& Selke, S. (2004). An overview of polylactides as packaging materials. Macromolecular Bioscience, 4(9), 835-864.

4. Auras, R.A., Singh, S.P., \& Singh, J.J. (2005). Evaluation of oriented poly(lactide) polymers vs. existing PET and oriented PS for fresh food service containers. Packaging Technology and Science, 18(4), 207-216.

5. Avella, M., De Vlieger, J.J., Errico, M.E., Fischer, S., Vacca, P., \& Volpe, M.G. (2008). Biodegradable starch/clay nanocomposite films for food packaging applications. Food Chemistry, 93(3), 467-474.

6. Baner, A. L., \& Piringer, O. (1999). Preservation of quality through packaging. In O.G. Piringer \& A.L. Baner (Eds.), Plastic packaging materials for foods (pp. 1-3). New York: Wiley-VCH.

7. Barry-Ryan, C., Pacussi, J.M., \& O'Beirne, D. (2000). Quality of shredded carrots as affected by packaging film and storage temperature. Journal of Food Science, 65(4), 726-730.

8. Biedrība „Latvijas Pārtikas uzñēmumu federācija" un nozares vadošie speciālisti. (2006). Atdzesētu, rūpnieciski ražotu gatavo produktu labas higiēnas un ražošanas prakses vadlīnijas. Retrieved from http://www.zm.gov.lv/doc upl/Atdzesetu,_rupnieciski_razotu_gatavo_ produktu_labas_higienas_prakses_vadlinijas.pdf

9. Carus, M. (2013). Market study on bio-based polymers. In World 6th Conference 2013 on Industrial Biotechnology and Bio-based Plastics \& Composites. Conference Journal 
(pp. 66-77). Cologne, Germany. Retrieved from http://www.biowerkstoff-kongress.de/media/ files/Flyer/Conference-Journal-2013.pdf

10. Dukalska,L., Muizniece-Brasava, S., Murniece, I., Dabina-Bicka, I., Kozlinskis, E., \& Sarvi, S. (2011). Influence of PLA film packaging on the shelf life of soft cheese Kleo. World Academy of Science, Engineering and Technology, 56, 295-301.

11. Dukalska, L., Ungure, E., Krasnova, I., Augspole, I., Muizniece Brasava, S., Levkane, V., \& Rakcejeva, T. (2012). Evaluation of various biodegradable packaging material influences on the shelf life and quality of different foods during storage [Poster presentation]. In The 5th International Symposium on Food Packaging Scientific Developments Supporting Safety and Innovation, 14-16 November 2012, Berlin, Germany. Retrieved from http://www.ilsi.org/ Europe/Documents/DUKALSKA.pdf

12. Dukalska, L., Muižniece-Brasava, S., \& Levkāne, V. (2008). LR patents Nr. 13702. Rīga: Patentu Valde.

13. Duni. (2012). FoodSolutions Catalog. Retrieved from http:/catalogues.duni.com/Spain/DFS/

14. Ecolean. (n.d.). Light on the planet. Retrieved from http://www.ecolean.com/en/environment

15. Eilert, S.J. (2005). New packaging technologies for the 21st century. Meat science, 71, 122-127.

16. European Bioplastics. (2011). Better packaging with bioplastic.s/Information on technology and market development. Fact sheet. Retrieved from http://en.european-bioplastics.org/wp-content/ uploads/2011/04/fs/Packaging_eng.pdf

17. Europe's Packaging Magazine. (2007, September). Plastic fantastic. Retrieved from http://www.packagingtoday.co.uk/story. asp? storycode $=51652$

18. Farris, S., Schaich, K.M., Liu, L.S., Piergiovanni, L., \& Yam, K.L. (2009). Development of polyion-complex hydrogels as an alternative approach for the production of bio-based polymers for food packaging applications: a review. Trends in Food Science and Technology, 20(8), 316-322.

19. Glaw, T. (2007, May). Transparent inorganic barrier properties. Retrieved from http:// www.tappi.org/content/events/07europlace/ presentation/07europl46.pdf

20. Green, R., \& Kunneman, D. (2006). PLA A Renewable/sustainable packaging option.
Retrieved from http://www.tappi.org/content/ enewsletters/eplace/2007/06PLA06.pdf

21. Grengross, T.U., \& Slater, S.C. (2000). How green are green plastics? Scientific American, 10, 25-28.

22. Innovia Films. (2006, July). First metallised natureflex film launched. Retrieved from http:// www.ferret.com.au/c/Innovia-Films/Firstmetallised-natureflex-film-launched-n696221

23. Innovia Films. (2008, September). New range of non-perforated 'Breathable' BOPP film. Retrieved from http://www.packaginggateway. com/contractors/materials/ubcfilmsplc/press22. html

24. Innovia Films. (n.d.). NatureFlex ${ }^{T M}$ films product range (Ref N100 Edition USA 0810). Retrieved from http://www.innoviafilms. com/InnoviaFilms-Kentico5/media/PDFs/ NATFLEX\%20DATA \%20SHEETS/ USA/ USA-N100-0810.pdf?ext=.pdf

25. Krasnova, I., Dukalska, L., Seglina, D., Juhnevica, K., Sne, E., \& Karklina, D. (2012). Effect of passive modified atmosphere in different packaging materials on fresh-cut mixed fruit salad quality during storage. World Academy of Science, Engineering and Technology, 67, 1095-1103. Retrieved from http://www.waset. org/journals/waset/v67/v67-197.pdf

26. Krasnova, I., Karklina, D., Seglina, D., Juhnevica, K., \& Kviesis, J. (2011). Assessment of apple cultivar quality and selection of the most suitable apple cultivars for fresh cut salad production. In Annual 17th International Scientific Conference, 18-20 May 2011 "Research for Rural Development", Vol. 1 (pp. 126-132). Jelgava, Latvia: Latvia University of Agriculture.

27. Levkane, V. (2011). Augsta riska pārtikas produktu kvalitātes izvērtējums Sous vide iepakojumā. Nepublicēts promocijas darbs. Latvijas Lauksaimniecības universitāte, Jelgava.

28. Levkane, V., Muizniece-Brasava, S., \& Dukalska, L. (2008). Pasteurization effect to quality with meat in mayonnaise. In The 3rd Baltic Conference on Food Science and Technology, 17-18 April 2008 (pp. 69-73). Jelgava, Latvia: Faculty of Food Technology.

29. Levkane, V., Muizniece-Brasava, S., \& Dukalska, L. (2010). The shelf life of Sous vide packaged ready-to-eat salad with meat in mayonnaise. In International Conference 
on Food Innovation "Food Innova 2010", 25-29 October 2010 (pp. 1-4). Valencia, Spain: Polytechnical University of Valencia.

30. Levkāne, V., Levkāne, V., Dukal̦ska, L., \& Muižniece-Brasava, S. (2010). LR patents Nr. 14025. Rīga: Patentu Valde.

31. Lopez-Rubio, A., Almenar, E., HernandezMunoz, P., Lagaron, J.M., Catala, R., \& Gavara, R. (2004). Overview of active polymer-based packaging technologies for food applications. Food Reviews International, 20(4), 357-387.

32. Marčenkova, T. (2010). Gatavo èdienu mikrobiologiskie kritêriji. Nepublicēts promocijas darbs. Latvijas Lauksaimniecības universitāte, Jelgava.

33. Meyer, A.R. (2007). Bio-packages to raise organic food's estimation. PLA bio-plastics trays for high-quality fresh foods and convenient foods under MAP. Fleischwirtschaft International, 5, 45-48. Retrieved from http://www.vc999.ch/ fileadmin/vc999/1.Marketing/1.6Pressespiegel/ Int_Fleischwirtschaft_PLA_EN_Dez07.pdf

34. Muizniece-Brasava, S., Dukalska, L., Kampuse, S., Murniece, I., Sabovics, M., Dabina-Bicka, I., ... Sarvi, S. (2011). Influence of active packaging on the shelf life of apple-black currant marmalade candies. World Academy of Science, Engineering and Technology, 56, 555-563.

35. Muizniece-Brasava, S., Dukalska, L., \& Kantike, I. (2011). Consumer's knowledge and attitude to traditional and environmentally friendly food packaging materials in market of Latvia. In The 6th Baltic Conference on Food Science and Technology "FoodBalt - 2011", 5-6 May 2011 (pp. 187-192). Jelgava, Latvia: Faculty of Food Technology.

36. Muizniece-Brasava, S., Dukalska, L., Murniece, I., Dabina-Bicka, I., Kozlinskis, E., Sarvi, S., ... Silvjane, A. (2012). Active packaging influence on shelf life extension of sliced wheat bread. World Academy of Science, Engineering and Technology, 67, 1128-1134.

37. Muizniece-Brasava, S., Dukalska L., Murniece, I., Sarvi, S., Dabina-Bicka, I., \& Kozlinskis, E. (2011). Influence of active packaging on the shelf life of soft cheese Kleo. In The 6th Baltic Conference on Food Science and Technology "Innovations for Food Science and Production”, 5-6 May 2011 (pp. 187-192), Jelgava, Latvia. Retrieved from http://llufb.
1lu.lv/conference/foodbalt/2011/FOODBALTProceedings-2011-193-198.pdf

38. Muizniece-Brasava, S., Saulite, K., Dukalska, L., \& Straumīte, E. (2007). Investigations on the shelf-life of cakes with raisins in environmentally friendly and conventional packaging. Chemie Technologija, 4(46), 72-78.

39. Muižniece-Brasava, S. (2006). Dabai draudzīga

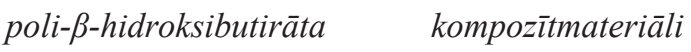
pārtikas produktu iepakojumam. Promocijas darba kopsavilkums inženierzinātnuu doktora zinātniskā grāda iegūšanai pārtikas zinātnē. Retrieved from http://lufb.llu.lv/dissertationsummary/food/kopsav-Sandra-MuiznieceBrasava.pdf

40. Packagingeurope. (2009, February). VC999 Bio Pack - First fully biodegradable packaging with CERAMIS®-PLA. Retrieved from http:// www.packagingeurope.com/NewsDetails. aspx?nNewsId=27793

41. Purac. (2012, January). Purac presents solutions for improved heat-resistant PLA at NPE 2012. Retrieved from http://www.purac.com/EN/ Bioplastics/News-Press-Events/News/Pressrelease-Improved-heat-resistant-PLA-at-NPE. aspx

42. Rakcejeva, T., Augspole, I., Dukalska, L., \& Dimins, F. (2012). Chemical composition of variety 'Nante' hybrid carrots cultivated in Latvia. World Academy of Science, Engineering and Technology, 64, 1120-1126. Retrieved from https://www.waset.org/journals/waset/v64/v64213.pdf

43. Robertson, G. (2008). Biobased food packaging materials: New directions. In E. Chielliny (Ed.), Environmentally compatible food packaging (pp. 1-24). Cambridge, England: Woodhead Publishing Ltd.

44. Rocha, A.M.C.N., \& Morais, A.M.M.B. (2003). Shelf life of minimally processed apple (cv. Jonagored) determined by colour changes. Food Control, 14, 13-20.

45. Shawaphun, S., \& Manangan, T. (2010). Paper coating with biodegradable polymer for food packaging. Science Journal Ubon Ratchathani University, 1(1), 51-57.

46. Shen, L., Haufe, J., \& Patel, M.K. (2009, June). Product overview and market projection of emerging bio-based plastics: PRO-BIP 2009. Retrieved from http://nws.chem.uu.nl/publica/ Publicaties\%202009/NWS-E-2009-32.pdf 
47. Siracusa, V., Rocculi, P., Romani, S., \& Rosa, D. (2008). Biodegradable polymers for food packaging. Trends in Food Science \& Technology, 19(12), 634-643.

48. Swift, G., \& Wiles, D.M. (2004). Biodegradable polymers and plastics in landfill sites. In H.F. Mark (Ed.), Encyclopedia of Polymer Science and Technology, Vol. 9 (pp. 40-50). New York: John Wiley \& Sons, Inc.

49. Taghleef Industries L.L.C. (2011a). NATIVIA ${ }^{\mathrm{TM}}$ food is a BoPLA film representing the new generation of compostable packaging and biodegradable films. Retrieved from http://www.ti-films.com/global/en/products/ products-bopla-nativia-food

50. Taghleef Industries L.L.C. (2011b). NATIVIA Tм. A new generation of packaging films made from renewable resources (PLA bio-based resin). Retrieved from http://www.ti-films.com/global/ en/products/bopla-introduction

51. Taghleef Industries L.L.C. (2012). Packaging solutions worldwide: NATIVATM biobased films. Retrieved from http:/www.ti-films.com/global/ en/products/bopla-brochures

52. Ungure, E., Muizniece-Brasava, S., \& Dukalska, L. (2011). Consumers' attitude to milk pomade sweet - sherbert consumption and its quality on the sales. In Annual 17th International Scientific Conference, 18-20 May 2011, "Research for Rural Development”, Vol. 1 (pp. 151-157). Jelgava, Latvia: Latvia University of Agriculture.

53. Ungure, E., Muizniece-Brasava, S., Dukalska, L., \& Levkane, V. (2012). Active packaging influence on the shelf life of milk pomade sweet - sherbet. World Academy of Science, Engineering and Technology, 67, 843-849.

54. Van Tuil, R., Fowler, P., Lawther, M., \& Weber, C.J. (2000). Properties of biobased packaging materials. In C.J. Weber (Ed.), Biobased Packaging Materials for the Food Industry - Status and Perspectives (pp. 13-44). Frederiksberg, Denmark: KVL.

55. Vorma, E., Muizniece-Brasava, S., Dukalska, L., \& Skalbe, J. (2010). Shelf life extension of milk pomade sweet - sherbet with crunchy peanut chips by MAP in various packaging materials. World Academy of Science, Engineering and Technology, 65, 1014-1020.

\section{Acknowledgements}

Publication and dissemination of the research results have been made due to the funding of the ERAF project "Promotion of scientific activities of LLU", Contract No. 2010/0198/2DP/2.1.1.2.0/10/APIA/VIAA/020. 